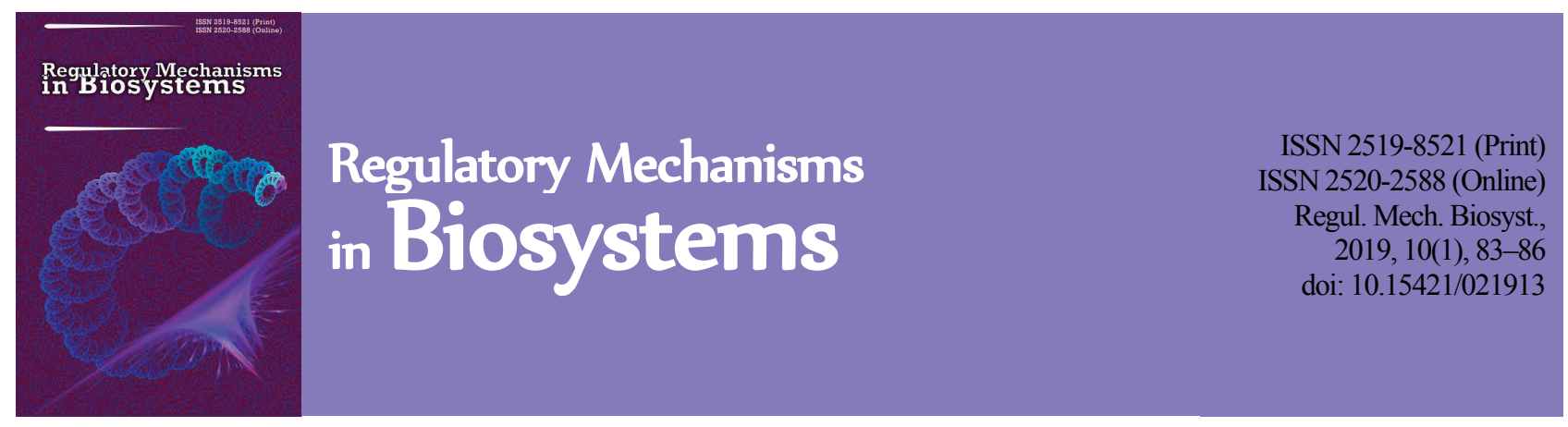

\title{
The usage of nitrogen compounds by purple non-sulfur bacteria of the Rhodopseudomonas genus
}

\author{
O. V. Tarabas, S. O. Hnatush, O. M. Moroz \\ Ivan Franko National University of Lviv, Lviv, Ukraine
}

Article info

Received 12.01.2019

Received in revised form 14.02.2019

Accepted 16.02.2019

Ivan Franko National University of Lviv,

Hrushevsky st., 4 ,

Lviv, 79005, Ukraine

Tel.: +38-067-291-08-68

E-mail:

otarabas@gmail.com
Tarabas, O. V., Hnatush, S. O., \& Moroz, O. M. (2019). The usage of nitrogen compounds by purple non-sulfur bacteria of the Rhodopseudomonas genus. Regulatory Mechanisms in Biosystems, 10(1), 83-86. doi:10.15421/021913

In this article, we characterized the regularities of oxidation of nitrite ions by phototropic purple non-sulfur bacteria Rhodopseudomonas yavorovii IMV B-7620, which were isolated from the water of Yavorivske Lake (Lviv Region, Ukraine). The bacteria were cultivated anaerobically at the light intensity of 200 lux and aerobically without illumination for 13 days in the modified ATCC No. 1449 medium. The concentration of nitrite ions was determined turbidimetrically by the turbidity of the solution by method of diazotization of sulfanilic acid by the nitrite ions and the interaction of the formed salt with n-(l-naphtyl)ethylenediamine dihydrochloride. The concentration of nitrate ions was determined turbidimetrically by the turbidity of the solution by method of diazotization. Zinc powder was used as a reducing agent. Efficiency of oxidation of $0.7-5.6 \mathrm{mM}$ nitrite ions as electron donors by these bacteria was $100-7 \%$, on the 10-th day of cultivation. It was established that nitrate ions were accumulated in the medium as a result of oxidation of nitrite ions by bacteria. The largest biomass $(1.6 \mathrm{~g} / \mathrm{L})$ bacteria accumulated on the thirteenth day of growth in a medium with $2.8 \mathrm{mM} \mathrm{NO}_{2}^{-}$. We found that $R$. yavorovii can use nitrate ions and urea as the only source of nitrogen for phototrophic growth. At a concentration of $1.9 \mathrm{mM}$ ammonium chloride, sodium nitrite and urea in the cultivation medium, the biomass of bacteria was $1.2,0.8,1.0 \mathrm{~g} / \mathrm{L}$, respectively. The ability of the studied microorganisms to oxidize nitrite ions and to use nitrate ions indicates the significant impact of purple non-sulfur bacteria on the redistribution of streams of nitrogen compounds in ecosystems and the essential role of these microorganisms in the nitrogen biogeochemical cycle.

Keywords: phototropic bacteria; nitrite ions; nitrate ions; nitrogen cycle.

\section{Introduction}

Nitrogen is a nutrient element of living cells and is part of many organic substances. In one or another form, it is located in all parts of the biosphere (Kozlova et al., 2008; Stein \& Klotz, 2016). The largest quantity of nitrogen is in the atmosphere and also in sedimentary rocks, where less than $2 \%$ of it is bioavailable (Galloway, 1998; Mackenzie et al., 1998). Since $\mathrm{CO}_{2}$ concentration in the atmosphere is constantly increasing, some researchers even predict that higher $\mathrm{CO}_{2}$ fixation rates can be achieved only by increasing the bioavailable concentration of nitrogen in the environment, which would significantly limit the global warming process (Luo et al., 2004; Langley \& Megonigal, 2010). Contribution of bacterial fixation of $\mathrm{CO}_{2}$ to the general assimilation of inorganic carbon in aquatic ecosystems has not been finally established. The dominant group here is formed by oxygenic phototropic cyanobacteria. Anoxygenic phototropic bacteria populate the boundary of the aerobic and anaerobic zones, where light penetrates from above and compounds of sulfur, ferrum and hydrogen penetrate from the bottom. The growth of these microorganisms is often limited by the lack of reduced substrates (Lengeler et al., 2005).

The nitrogen cycle is one of the main global oxidation reduction cycles (Canfield et al., 2010; Galloway et al., 2013). In the cycle of nitrogen compounds various microorganisms play an important role (Simon \& Klotz, 2013). Nitrite ions are the intermediate products of various metabolic pathways of microorganisms. Under anaerobic conditions, nitrate or nitrite ions are electron acceptors in the process of anaerobic respiration, which is realized by two different reductive paths with different end products (Galloway, 1998; Kozlova et al., 2008; Stein \& Klotz, 2016). During denitrification, nitrate ions are reduced through nitrites, nitrogen oxide and nitrogen oxide to nitrogen as is shown in reactions 1-5 (Stolz \& Basu, 2002; Lengeler et al., 2005; Kozlova et al., 2008), while the dissimilatory reduction of nitrate ions to ammonia occurs through the recovery of nitrite ions directly to ammonia, with the participation of nitrite reductase in reaction 6 (Einsle et al., 2002; Kozlova et al., 2008). During anammox reactions, nitrite ions and ammonia are converted into nitrogen, although the metabolic pathway of this transformation in microorganism cells is not yet fully understood (Francis et al., 2007; Stein \& Klotz, 2016). Assimilative reduction of nitrate ions to ammonia is carried out in a similar way, although various enzymes with different regulation mechanisms are involved. This process takes place both under aerobic and anaerobic conditions of microorganisms' growth (Stolz \& Basu, 2002; Kozlova et al., 2008). Another assimilation pathway is reductive fixation of nitrogen and formation of ammonium, which occurs under anaerobic conditions (Kozlova et al., 2008).

$$
\begin{aligned}
\mathrm{NO}_{3}^{-}+2 \mathrm{e}^{-}+2 \mathrm{H}^{+} \stackrel{\mathrm{A}}{\mathrm{B}} \longrightarrow \mathrm{NO}_{2}^{-}+\mathrm{H}_{2} \mathrm{O} \\
\mathrm{NO}_{2}^{-}+\mathrm{e}^{-}+2 \mathrm{H}^{+} \stackrel{\mathrm{C}}{\longrightarrow} \mathrm{NO}+\mathrm{H}_{2} \mathrm{O} \\
2 \mathrm{NO}+2 \mathrm{e}^{-}+2 \mathrm{H}^{+} \stackrel{\mathrm{D}}{\longrightarrow} \mathrm{N}_{2} \mathrm{O}+\mathrm{H}_{2} \mathrm{O} \\
2 \mathrm{~N}_{2} \mathrm{O}+2 \mathrm{e}^{-}+2 \mathrm{H}^{+} \stackrel{\mathrm{E}}{\longrightarrow} \mathrm{N}_{2}+\mathrm{H}_{2} \mathrm{O} \\
\mathrm{NO}_{2}^{-}+3 \mathrm{NAD}(\mathrm{P}) \mathrm{H}+5 \mathrm{H}^{+} \stackrel{\mathrm{C}}{\longrightarrow} \mathrm{NH}_{4}^{+}+3 \mathrm{NAD}(\mathrm{P})^{+}+2 \mathrm{H}_{2} \mathrm{O}
\end{aligned}
$$
Enzymes: A - nitrate reductase; $\mathrm{B}-\mathrm{NO}$-forming nitrite reductase; $\mathrm{C}-$ NO-reductase; $\mathrm{D}-\mathrm{N}_{2} \mathrm{O}$-reductase; $\mathrm{E}-\mathrm{NH}_{3}$-forming nitrite reductase.

In many reactions of the nitrogen cycle, molybdenum is a necessary cofactor and is a part of nitrogenase or nitrate reductase (Kroneck \& 
Abt, 2002; Kozlova et al., 2008; Schwarz et al., 2009). As was described above, the reduction of nitrates to nitrites occurs in two different metabolic pathways and with the participation of at least three different enzymes. The assimilation of nitrate ions to ammonia is carried out by cytoplasmic nitrate reductase encoded by nasA, and the dissimilatory reduction of nitrate ions to ammonia and denitrification occur with the participation of either periplasmic nitrate reductase encoded by napA or membrane-bounded nitrate reductase encoded by narG (Galloway, 1998; Kozlova et al., 2008).

Phototropic bacteria use nitrogen compounds in the processes of assimilation and dissimilation. Usually ammonia is the best source of nitrogen for these microorganisms, but some phototropic strains use nitrates if ammonia is not present in the medium (Olmo-Mira et al., 2006; Pino et al., 2006). These microorganisms directly influence the nitrogen cycle through reductive processes such as nitrogen fixation, assimilation and respiration (Megonigal et al., 2003; Hoffman et al., 2014; Arashida et al., 2018). Anaerobic oxidation of nitrite ions is the only example in the nitrogen cycle which takes place with the participation of phototrophs. This photosynthetic process can compete with other key nitrogen cycle processes, such as denitrification, aerobic nitrification or anammox-reaction.

Purple non-sulfur bacteria Rhodopseudomonas yavorovii IMV B7620, isolated by us from Yavorivske Lake (Lviv Region, Ukraine) (Tarabas et al., 2017b; 2017d), can use sulfide and thiosulfate ions as electron donors in the process of anoxygenic photosynthesis (Tarabas et al., 2017c). They also form hydrogen while growing in the medium with malate (Tarabas et al., 2017a). Since the oxidation of nitrite ions under anaerobic conditions in the light is an entirely new alternative to the already known aerobic oxidation of nitrites, we set the goal of investigating the bacteria $R$. yavorovii for the ability of anaerobic phototrophic oxidation of nitrite ions in order to understand their potential role in the oxidation of nitrites in nature. Obtaining new data may allow us to draw conclusions about the possible impacts of this poorly-studied metabolic process on the global nitrogen cycle.

\section{Materials and methods}

The object of the study was the culture of purple non-sulfur bacteria R. yavorovii (Tarabas et al., 2017b; 2017d). The bacteria were grown anaerobically at the light intensity of 200 lux and aerobically without illumination in $25 \mathrm{ml}$ tubes at the temperature of $+27 \ldots+30^{\circ} \mathrm{C}$. Microorganisms were cultivated for 13 days in the modified ATCC No. 1449 medium of such composition $(\mathrm{g} / \mathrm{L})$ : ammonium chloride -0.4 , potassium dihydrophosphate -0.6 , calcium chloride dihydrate -0.05 , magnesium sulfate heptahydrate -0.32 , sodium acetate trihydrate $-0.816, \mathrm{pH}$ of the medium was 7.0-7.3. The initial concentration of cells was $0.20 \pm$ $0.01 \mathrm{~g} / \mathrm{L}$. The intensity of light was measured using the lux-meter U-116.

To study the influence of nitrite ions on biomass accumulation and usage of them by bacteria, various concentrations of sodium nitrite: 0.7 , $1.4,2.8,5.6 \mathrm{mM}$, were added to the cultivation medium. In order to investigate the usage of different compounds of nitrogen by the examined microorganisms, sodium nitrate and urea were introduced into the cultivation medium instead of ammonium chloride $(1.9 \mathrm{mM})$. To test the ability of $R$. yavorovii for nitrogen fixation, the bacteria were cultivated in a modified ATCC No. 1449 medium without ammonium ions for 19 days. To study the influence of molybdenum on the biomass accumulation and the usage of nitrite ions by bacteria, sodium molybdate was introduced into the cultivation medium at a concentration of $300 \mathrm{nM}$.

The biomass was measured turbidimetrically using a photoelectroncolorimeter KFK-3 $(\lambda=660 \mathrm{~nm})$. The concentration of nitrite ions was determined by photometric method which is based on the reaction of diazotization of sulfanilic acid by the nitrite ions and the interaction of the formed salt with n-(l-naphtyl)ethylenediamine dihydrochloride (Granger, 1996). The concentration of $\mathrm{NO}_{2}^{-}$was determined turbidimetrically by the turbidity of the solution using the photoelectrocolorimeter KFK-3 $(\lambda=540 \mathrm{~nm}, 1=10 \mathrm{~mm}$ ), and calculated by the formula (Granger, 1996): $\mathrm{C}=\mathrm{E} \cdot \mathrm{n} / \mathrm{K}$, where: $\mathrm{C}-$ a concentration of $\mathrm{NO}_{2}^{-}(\mathrm{mM}), \mathrm{E}-$ an extinction rate at $540 \mathrm{~nm}$ wavelength, $\mathrm{n}$ - dilution (times), $\mathrm{K}$ - the coefficient determined by the calibration curve $(\mathrm{K}=15.03)$.
Determination of nitrate ions concentration was based on their reduction to nitrites in the presence of $\mathrm{Zn} / \mathrm{MnSO}_{4}$ as a reducing agent. The produced nitrites were subsequently diazotized with sulfanilic acid then coupled with n-(1-naphtyl)ethylenediamine dihydrochloride to form an azo dye, the content of which was measured at $540 \mathrm{~nm}$ (Granger, 1996). The concentration of $\mathrm{NO}_{3}^{-}$was determined turbidimetrically by the turbidity of the solution using the photoelectrocolorimeter KFK-3 $(\lambda=540 \mathrm{~nm}, 1=10 \mathrm{~mm})$ and calculated according to the formula (Granger, 1996): $\mathrm{C}=\mathrm{E} \cdot \mathrm{n} / \mathrm{K}$, where: $\mathrm{C}-\mathrm{a}$ concentration of $\mathrm{NO}_{2}^{-}(\mathrm{mM}), \mathrm{E}-$ an extinction rate of $540 \mathrm{~nm}$ wavelength, $\mathrm{n}$ - dilution (times), $\mathrm{K}$ - the coefficient determined by the calibration curve $(\mathrm{K}=5.0)$.

Experiments were repeated three times with three parallel formulations for each variant of experimental and control conditions. The obtained data were processed by generally accepted methods of variation statistics. The reliability of the difference was evaluated using ANOVA. Differences between the samples were considered reliable at $\mathrm{P}<0.05$.

\section{Results}

In this research we investigated the ability of $R$. yavorovii to use various nitrogen compounds as a source of this element in assimilation processes at a concentration of $1.9 \mathrm{mM}$ at an intensity of illumination of 200 lux in anaerobic conditions on 10th day of cultivation in the modified medium of ATCC No. 1449. The studied microorganisms use ammonium chloride, urea and sodium nitrate as the nitrogen source (Table 1$)$. The largest biomass $(1.2 \mathrm{~g} / \mathrm{L})$ of bacteria $R$. yavorovii accumulated in medium with ammonium chloride. When urea or sodium nitrate was added to the cultivation medium the accumulation of biomass by bacteria was lower. So, when sodium nitrate was introduced into the cultivation medium, the bacteria accumulated the biomass of $0.8 \mathrm{~g} / \mathrm{L}$ (Fig. 1).

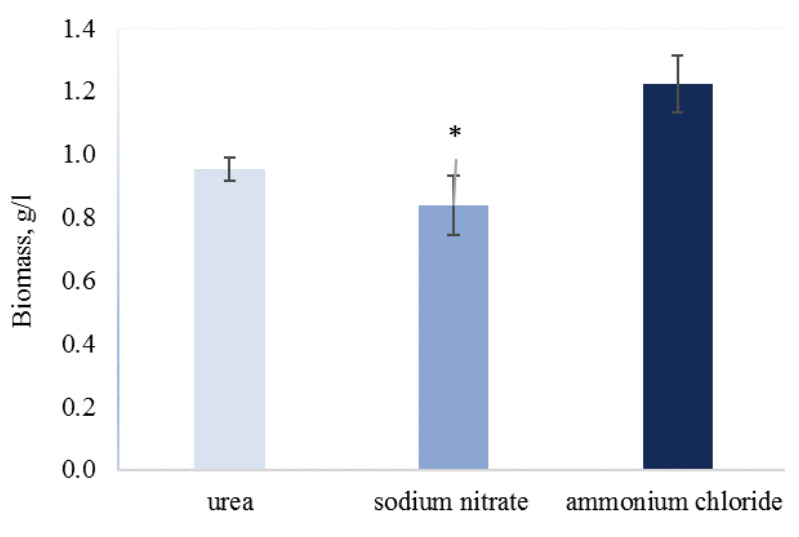

Nitrogen source

Fig. 1. Effect of various nitrogen compounds on the biomass accumulation by bacteria $R$. yavorovii on the 10-th day of cultivation $(\mathrm{P}<0.05 ; \mathrm{n}=9)$

Since the investigated microorganisms grow in the urea-containing medium, they obviously contain urease. $R$. yavorovii and other species of this genus (Table 1) use ammonium as a nitrogen source. $R$. yavorovii IMV B-7620, Rhodopseudomonas harwoodiae JA531, Rhodopseudomonas cryptolactis grow in urea-containing media. $R$. yavorovii IMV B-7620, Rhodopseudomonas parapalustris JA310, Rhodopseudomonas pentothenatexigens JA575, Rhodopseudomonas thermotolerans, Rhodopseudomonas palustris, in contrast to Rhodopseudomonas julia and $R$. harwoodiae JA531 use nitrate ions under anaerobic conditions in the light (Table 1).

Since fixation of molecular nitrogen is a widespread process among most phototropic bacteria (Kozlova, 2008), we examined the capacity of $R$. yavorovii for nitrogen fixation. In case of cultivation on a modified nutrient medium ATCC No. 1449 without ammonium chloride as a nitrogen source, the bacteria accumulated biomass of $0.7 \mathrm{~g} / \mathrm{L}$ for 16 day of cultivation (Fig. 2). Obviously, $R$. yavorovii is capable of molecular nitrogen fixation. Sulfur compounds, in particular, hydrogen sulfide, thiosulfate, tetrathionate and others, are well-studied as electron donors 
of anoxygenic photosynthesis. The processes of nitrogen compounds' oxidation in the course of photosynthesis were not well known and studied. We studied the influence of nitrite ions on the biomass accumulation by bacteria $R$. yavorovii. The bacteria did not grow in the modified ATCC No. 1449 medium with nitrite ions without addition of sodium molybdate. Therefore, further studies of the influence of nitrite ions on bacteria were carried out in a medium containing sodium molybdate. The largest biomass $(1.6 \mathrm{~g} / \mathrm{L})$ bacteria accumulated on the thirteenth day of growth in a medium with $2.8 \mathrm{mM} \mathrm{NO}_{2}^{-}$. The lowest biomass $(0.4 \mathrm{~g} / \mathrm{L})$ accumulated in bacteria stored in a medium with $5.6 \mathrm{mM}$ nitrite ions.

\section{Table 1}

The usage of various nitrogen compounds

by bacteria of Rhodopseudomonas genus during photosynthesis

\begin{tabular}{lccc}
\hline \multirow{2}{*}{\multicolumn{1}{c}{ Microorganisms }} & \multicolumn{3}{c}{ Nitrogen source } \\
\cline { 2 - 4 } & $\mathrm{NH}_{4}^{+}$ & $\mathrm{NO}_{3}^{-}$ & $\mathrm{CH}_{4} \mathrm{~N}_{2} \mathrm{O}$ \\
\hline R. yavorovii IMV-7620 & + & + & + \\
R. parapalustris $\mathrm{JA} 310^{\mathrm{T}}$ (Ramana et al., 2012) & + & + & $\mathrm{ND}$ \\
R. harwoodiae JA531 (Ramana et al., 2012) & + & - & + \\
R.faecalis JCM11668 ${ }^{\mathrm{T}}$ (Zhang et al., 2002) & + & $\mathrm{ND}$ & $\mathrm{ND}$ \\
R. pentothenatexigens JA575 (Kumar et al., 2013) & + & + & - \\
R. thermotolerans (Kumar et al., 2013) & + & + & - \\
R. cryptolactis (Imhoff et al., 2005) & + & $\mathrm{ND}$ & + \\
R. palustris (Imhoff et al., 2005) & + & + & $\mathrm{ND}$ \\
R. julia (Imhoff et al., 2005) & + & - & $\mathrm{ND}$ \\
R. rhenobacensis (Imhoff et al., 2005) & + & $\mathrm{ND}$ & $\mathrm{ND}$ \\
\hline
\end{tabular}

Note: "+"- occurrence of growth; "-_"-no growth; ND-no data.

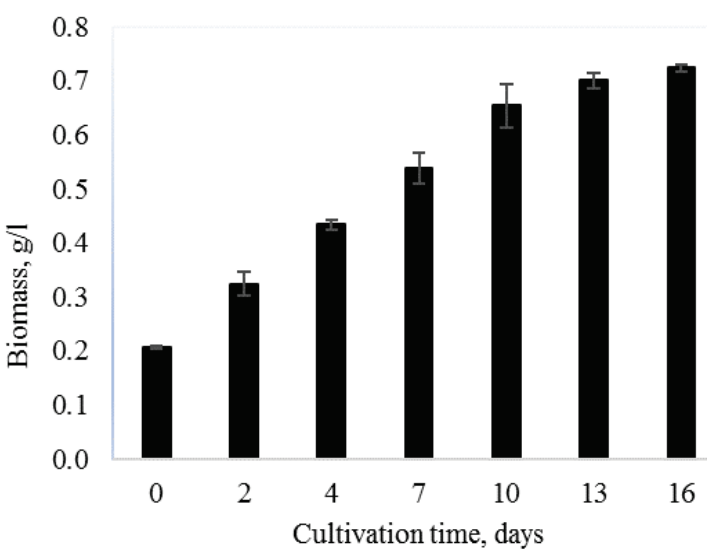

Fig. 2. Biomass of purple non-sulfur bacteria $R$. yavorovii during growth in a modified ATCC No. 1449 medium without $\mathrm{NH}_{4} \mathrm{Cl}$ as nitrogen source $(\mathrm{P}<0.05 ; \mathrm{n}=9)$

In the medium with $0.7 \mathrm{mM}$ nitrite ions, bacteria use them at $100 \%$, and with increase in concentration to $1.4 \mathrm{mM}$ they use it at $93.7 \%$ on the tenth day of cultivation (Fig. $3 b$ ). The bacteria oxidized the nitrite ions during thirteen days of cultivation at their initial concentration of $2.8 \mathrm{mM}$ by $86.1 \%$ (Fig. 3). Probably, the deceleration of nitrite ions oxidation by bacteria at high concentrations in the medium is the result of the inhibition of photosynthetic, and, therefore, growing processes under these conditions. Obviously, R. yavorovii uses nitrite ions as electron donors during the anoxygenic photosynthesis.

During 13 days of cultivation as a result of nitrite ions oxidation at their initial concentrations of $0.7,1.4,2.8,5.6 \mathrm{mM}$ in the medium nitrate ions were accumulated, the concentration of which on the 10th day of cultivation was $0.19,0.64,0.84,0.03 \mathrm{mM}$, respectively (Fig. 4). $R . y a-$ vorovii use nitrate ions in the processes of assimilation, as is proved by the biomass accumulation by investigated microorganisms (Fig. 1).

\section{Discussion}

Sulfur compounds, in particular, hydrogen sulfide, thiosulfate, tetrathionate and others, are well-studied as electron donors of anoxygenic photosynthesis (Neutzling et al., 1984; Ghosh \& Dam, 2009; Hallenbeck, 2017). In this paper we describe anaerobic oxidation of nitrite ions by $R$. yavorovii bacteria. In the process of nitrite ions' oxidation by the studied microorganisms in light under anaerobic conditions, these ions are electron donors. $R$. yavorovii as well as Thiocapsa sp. strain KS1 and Rhodopseudomonas sp. strain LQ17 (Schott et al., 2010) uses nitrites as electron donors during anoxygenic photosynthesis. The pair of $\mathrm{NO}_{3}{ }^{-} \mathrm{NO}_{2}{ }^{-}$with a standard oxidation reduction potential $(\mathrm{ORP})+0.43 \mathrm{~V}$, theoretically, can emit electrons in the reaction center of the quinone type in purple sulfur bacteria, where the primary donor bacteriochlorophyll has middle ORP $+0.49 \mathrm{~V}$ (Cusanovich et al., 1965; Schott et al., 2010). As was noted above, the nitrite-ion is an electron acceptor during the dissimilatory reduction of nitrates to ammonia under anaerobic conditions, denitrification to nitrogen and anammox-reaction by different groups of microorganisms. A single process of aerobic nitrification is known to exist, in which electrons from nitrite ions are transferred to oxygen (Bock et al., 1991). In Wolinella succigenes, the reduction of nitrites to ammonium occurs with the involvement of hydrogen or membrane-bound nitrite reductase. Reduced menaquinone serves as an electron donor to these microorganisms (Lengeler et al., 2005).

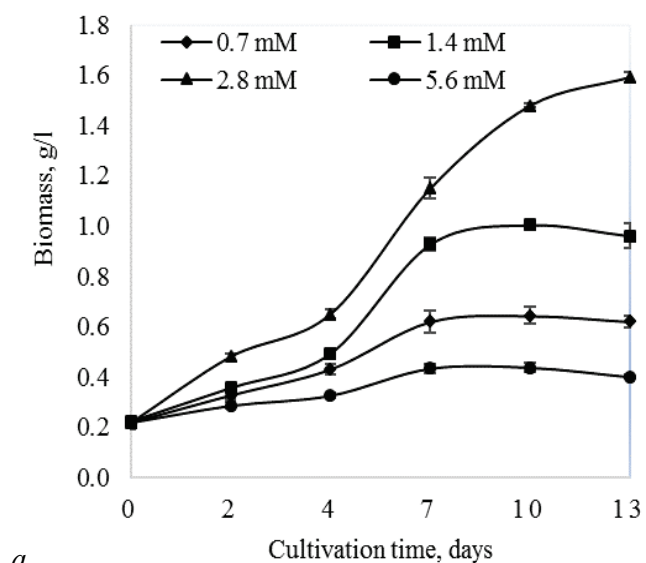

$a$ Cultivation time, days
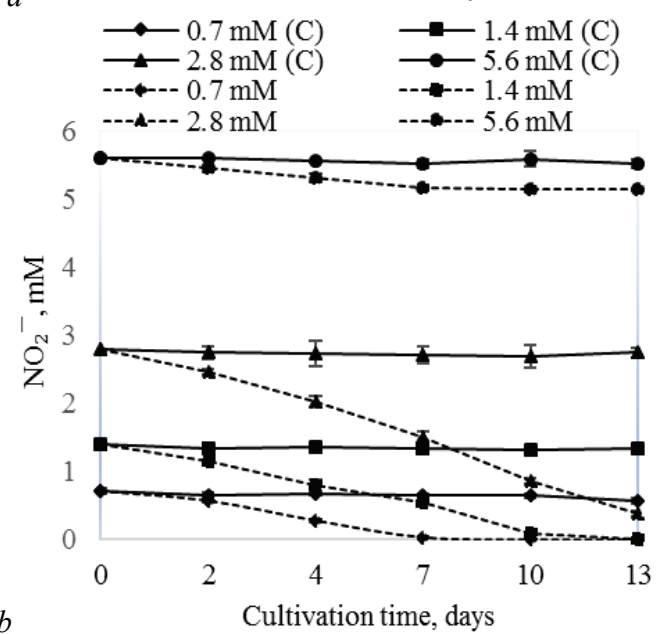

Fig. 3. Biomass $(a)$ and $\mathrm{NO}_{2}^{-}$usage (b) by $R$. yavorovii during growth in medium with $\mathrm{NO}_{2}^{-}$at different concentrations $(\mathrm{P}<0.05 ; \mathrm{n}=9)$

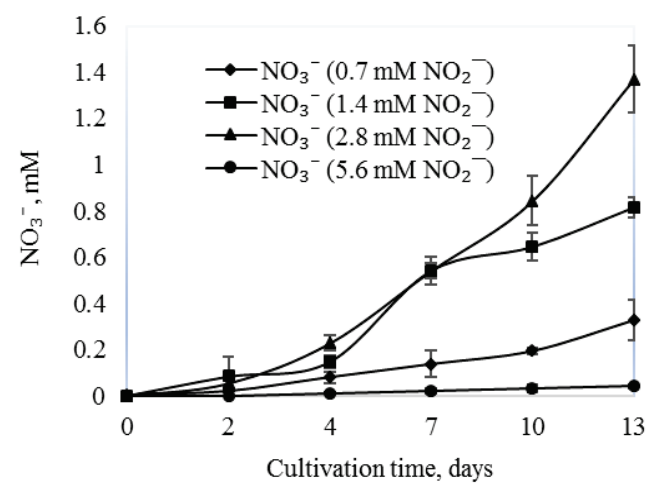

Fig. 4. Nitrate ions accumulation by bacteria $R$. yavorovii in the media with nitrite ions at different concentrations $(\mathrm{P}<0.05 ; \mathrm{n}=9)$ 
Assimilative reduction of nitrate ions to ammonia takes place both under aerobic and anaerobic conditions of a microorganism's growth (Stolz \& Basu, 2002). Reductive fixation of nitrogen and formation of ammonium by most phototropic bacteria occurs under anaerobic conditions (Kozlova et al., 2008). R. yavorovii under these conditions is capable of molecular nitrogen fixation, as are also $R$. palustris, $R$. rhenobacensis, $R$. cryptolactis (Imhoff et al., 2005).

We have found that nitrite ions were oxidized to nitrates only under anaerobic conditions while bacteria were growing in the light. In the medium free of cells (control), no oxidation of nitrite ions to nitrate ions was observed under illumination conditions, thus chemical oxidation of nitrites to nitrates was excluded. Under aerobic chemotrophic conditions of growth, oxidation of nitrite ions by the bacteria $R$. yavorovii was not observed. The study of the growth of $R$. yavorovii in the medium with sodium nitrite with and without introduction of molybdenum was conducted to determine whether this metal is involved in this process, since all nitrate reductases, which catalyzing the nitrates to nitrites reduction, contain molybdenum as cofactor (Kroneck \& Abt, 2002; Stolz \& Basu, 2002; Schwartz et al., 2009). It has been established that bacteria accumulate biomass and oxidize nitrite ions only when molybdenum is introduced into the cultivation medium. Therefore, we assume that the nitrite oxidizing enzyme in $R$. yavorovii bacteria contains a molybdopterin cofactor.

\section{Conclusions}

The patterns we established of usage of nitrite ions as electron donors of anoxygenic photosynthesis by $R$. yavorovii under anaerobic phototrophic conditions of cultivation supplement and broaden the understanding of the role of purple non-sulfur bacteria in nitrogen compound oxidation in ecosystems.

\section{References}

Arashida, H., Kugenuma, T., Watanabe, M., \& Maeda, I. (2018). Nitrogen fixation in Rhodopseudomonas palustris co-cultured with Bacillus subtilis in the presence of air. Journal of Bioscience and Bioengineering, 18, 1389-1723.

Bock, E., Koops, H.-P., Ahlers, B., \& Harms, H. (1991). Oxidation of inorganic nitrogen compounds as energy source. In: Balows, A., Trüper, H. G., Dworkin, M., Harder, W., Schleifer, K. H. (Eds.). The prokaryotes. Springer Verlag, New York. Pp. 414430.

Canfield, D. E., Glazer, A. N., \& Falkowski, P. G. (2010). The evolution and future of Earth's nitrogen cycle. Science, 330, 192-196.

Cusanovich, M. A., Bartsch, R. G., \& Kamen, M. D. (1968). Light-induced electron transport in Chromatium strain D. II. Light-induced absorbance changes in Chromatium chromatophores. Biochimica et Biophysica Acta - Bioenergetics, 153(2), 397-417.

Elser, J. J., Bracken, M. E., Cleland, E. E., Gruner, D. S., Harpole, W. D., Hillebrand, H., Ngai, J. G., Seabloom, E. W., Shurin, J. B., \& Smith, J. E. (2007). Global analysis of nitrogen and phosphorus limitation of primary producers in freshwater, marine and terrestrial ecosystems. Ecology Letters, 10(12), 1135-1142.

Galloway, J. N. (1998). The global nitrogen cycle: Changes and consequences. Environmental Pollutions, 102, 15-24.

Galloway, J. N., Leach, A. M., Bleeker, A., \& Erisman, J. W. (2013). A chronology of human understanding of the nitrogen cycle. Philosophical Transactions of the Royal Society of London. Series B. Biological Sciences, 368(1621), 20130120

Ghosh, W., \& Dam, B. (2009). Biochemistry and molecular biology of lithotrophic sulfur oxidation by taxonomically and ecologically diverse bacteria and archaea. FEMS Microbiology Reviews, 33(6), 999-1043.

Granger, D. L., Taintor, R. R., Boockvar, K. S., \& Hibbs, J. B. (1996). Measurement of nitrate and nitrite in biological samples using nitrate reductase and Griess reaction. Methods Enzymology, 268, 142-151.

Hallenbeck, P. C. (2017). Modern topics in the phototrophic prokaryotes. Springer International Publishing AG.

Hoffman, B. M., Lukoyanov, D., Yang, Z. Y., Dean, D. R., \& Seefeldt, L. C. (2014) Mechanism of nitrogen fixation by nitrogenase: The next stage. Chemical Reviews, 114(8), 4041-4062.

Imhoff, J. F., Hiraishi, A., \& Suling, J. (2005). Bergey's manual of systematic bacteriology. The Proteobacteria. Part C. The Alpha-, Beta-, Delta-, and Epsilonproteobacteria. Garrity, G. M, Staley, J. T., Krieg, N. R., \& Brenner, D. J. (Eds.). Springer, USA.
Kozlova, I. P., Radchenko, O. S., Stepura, L. H., Kondratyuk, T. O., \& PilyashenkoNovokhatnyy, A. I. (2008). Heokhimichna diyalnist mikroorhanizmiv ta yiyi prykladni aspekty [Geochemical activity of microorganisms and its applied aspects]. Naukova Dumka, Kyiv (in Ukrainian).

Kroneck, P. M. H., \& Abt, D. J. (2002). Molybdenum in nitrate reductase and nitrite oxidoreductase. In: Sigel, A., \& Sigel, H. (Eds.). Molybdenum and tungsten. Their roles in biological processes. M. Dekker Inc., New York.

Kumar, B. V., Ramprasad, E. V. V., Sasikala, C., \& Ramana, C. V. (2013). Rhodopseudomonas pentothenatexigenes sp. nov. and Rhodopseudomonas thermotolerans sp. nov., isolated from paddy soils. International Journal of Systematic and Evolutionary Microbiology, 63, 200-207.

Langley, J. A., \& Megonigal, J. P. (2010). Ecosystem response to elevated $\mathrm{CO}_{2}$ levels limited by nitrogen-induced plant species shift. Nature, 466, 96-99.

Lengeler, J., Drevs, G., \& Shlegel, G. (Eds.). (2005). Sovremennaya mikrobiologiya. Prokarioty [Contemporary Microbiology. Prokaryotes]. Mir, Moscow (in Russian).

Luo, Y., Su, B., Currie, W. S., Dukes, J. S., Finzi, A., Hartwig, U., Hungate, B., Mcmurtrie, R. E., Oren, R., Parton, W. J., Pataki, D. E., Shaw, M. R., Zak, D. R., \& Field, C. B. (2004). Progressive nitrogen limitation of ecosystem responses to rising atmospheric carbon dioxide. Bioscience, 54(8), 731-739.

Mackenzie, F. T. (1998). Our changing planet: An introduction to earth system science and global environmental change. Prentice-Hall, Upper Saddle River, New Jersey.

Megonigal, J. P., Hines, M. E., \& Visscher, P. T. (2003). Anaerobic metabolism: Linkages to trace gases and aerobic processes. In: Schlesinger, W. H. (Ed.). Treatiseon geochmistry. Elsevier, Amsterdam, 8, 317-424.

Neutzling, O., Imhoff, J. F., \& Truper, H. G. (1984). Rhodopsendomonas adriatica sp. nov., a new species of the Rhodospirillaceae, dependent on reduced sulfur compounds. Archives of Microbiology, 137, 256-261.

Olmo-Mira, M. F., Cabello, P., Pino, C., Martınez-Luque, M., Richardson, D. J., Castillo, F., Roldan, M. D., \& Moreno-Vivian, C. (2006). Expression and characterization of the assimilatory NADH nitrite reductase from the phototrophic bacterium Rhodobacter capsulatus E1F1. Archives of Microbiology, $186,339-344$.

Ramana, V. V., Chakravarthy, S. K., Raj, P. S., Kumar, B. V., Shobha, E., Ramaprasad, E. V. V., Sasikala, C., \& Ramana, C. V. (2012). Descriptions of Rhodopseudomonas parapalustris sp. nov., Rhodopseudomonas harwoodiae sp. nov. and Rhodopseudomonas pseudopalustris sp. nov., and emended description of Rhodopseudomonas palustris. International Journal of Systematic Evolutionary Microbiology, 62, 1790-1798.

Schott, J., Griffin, B. M., \& Schink, B. (2010). Anaerobic phototrophic nitrite oxidation by Thiocapsa sp. strain KS1 and Rhodopseudomonas sp. strain LQ17. Microbiology, 156, 2428-2437.

Schwartz, G., Mendel, R. R., \& Ribbe, M. W. (2009). Molybdenum cofactors, enzymes and pathways. Nature, 460(7257), 839-847.

Simon, J., \& Klotz, M. G. (2013). Diversity and evolution of bioenergetic systems involved in microbial nitrogen compound transformations. Biochimica et Biophysica Acta, 1827, 114-135

Stein, L. Y., \& Klotz, M. G. (2016). The nitrogen cycle. Current Biology, 26(3), R94-R98

Stolz, J. F., \& Basu, P. (2002). Evolution of nitrate reductase: Molecular and structural variations on a common function. ChemBioChem, 3(2-3), 198-206.

Tarabas, O. V., Hnatush, S. O., Moroz, O. M., \& Ostash, B. O. (2017b). Svidotstvo pro deponuvannya shtamu bakteriy Rhodopseudomonas yavorovii Ya2016 z nadannyam reyestracijnogo nomeru IMV B-7620 vid 01.08.2017 u Depozytariyi Instytutu mikrobiolohiyi i virusolohiyi im. D. K. Zabolotnoho NAN Ukrayiny, Kyiv [Certificate of deposition of bacteria Rhodopseudomonas yavorovii Ya-2016 strain with appropriation of registration number IMV B-7620 from 01.08.2017 at the Depository of D. K. Zabolotny Institute of Microbiology and Virology of the NAS of Ukraine, Kyiv] (in Ukrainian)

Tarabas, O. V., Hnatush, S. O., Moroz, O. M., Vasilechko, V. O., Grishhuk G. V., Zvir, G. I., \& Komplikevich, S. J. (2017c). Vykorystannja sul'fid- ta tiosul'fat-joniv purpurovymy nesirkovymy bakterijamy Rhodopseudomonas yavorovii Ya-2016 [The usage of sulfide and thiosulfate ions by purple nonsulfur bacteria Rhodopseudomonas yavorovii Ya-2016]. Biosystems Diversity, 25(3), 181-185.

Tarabas, O. V., Hnatush, S. O., Ostash, B. O., Mutenko, G. V., \& Koshla, O. V. (2017d). Identifikacija purpurovih nesirkovih bakterij Rhodopseudomonas sp. Ya-2016 [Identification of purple non-sulfur bacteria of Rhodopseudomonas sp. Ya-2016]. Visnyk of Lviv University, Biological Series, 75, 140-145 (in Ukrainian).

Tarabas, O., Hnatush, S., Govorukha, V., Tashyrev, O., \& Moroz, O. (2017a). Production of molecular hydrogen by purple non-sulfur bacteria Rhodopseudomonas yavorovii Ya-2016. 7th International Weigl Conference, Lviv. Pp. 188.

Zhang, D., Yang, H., Huang, Z., Zhang, W., \& Liu, S. J. (2002). Rhodopseudomonas faecalis sp. nov., a phototrophic bacterium isolated from an anaerobic reactor that digests chicken faeces. International Journal of Systematic Evolutionary Microbiology, 52, 2055-2060. 